Eur J Clin Chem Clin Biochem

1995; 33:121-126

(C) 1995 Walter de Gruyter \& Co.

Berlin · New York

\title{
Effects of Long-Term Exercise of Moderate Intensity on Anthropometric Values and Serum Lipids and Lipoproteins
}

\author{
By Gabriëlle A. E. Ponjee', Eugene M. E. Janssen ${ }^{2}$, Jo Hermans ${ }^{3}$ and Jan W. J. van Wersch ${ }^{4}$ \\ 1 Diagnostisch Centrum SSDZ, Delft, The Netherlands \\ 2 Nederlands Sport Instituut Geneeskunde, Arnhem, The Netherlands \\ 3 Universiteit van Leiden, Leiden, The Netherlands \\ 4 "De Wever" Ziekenhuis, Heerlen, The Netherlands
}

(Received September 15, 1994/January 13, 1995)

Summary: The influence of endurance training on serum lipids and lipoproteins was investigated in 20 sedentary males and 14 sedentary females. The total group was trained 3 to 4 times a week for 9 months. After 24 weeks all subjects ran a $15 \mathrm{~km}$-race and after 36 weeks a half-marathon $(21 \mathrm{~km})$ race. Anthropometric values were determined before and after the training programme. Blood samples were drawn before the start of the training programme and, in order to avoid the measurement of acute effects, 5 days before both races. In the male group, median body weight and body mass were significantly decreased $(p<0.01)$ after nine months of training, while in the female group body weight and body mass index remained essentially unchanged. Percentage body fat, measured by skinfold thickness was significantly decreased in both groups at the end of the training programme. During the training period, median serum total cholesterol, low density lipid cholesterol and triacylglycerol concentrations decreased significantly $(\mathrm{p}<0.01)$ in the male group, while in the female population the median serum lipid- and lipoprotein concentrations did not differ from pre-training values. The changes in serum lipids or lipoproteins did not correlate significantly with changes in body weight, body mass index or percentage body fat. Stepwise multiple regression showed that these changes were mostly dependent on initial concentrations in serum. Finally, no significant increase in median high density lipid cholesterol was observed in either the male or female group. In conclusion, the results from our study demonstrate that prolonged physical conditioning of moderate intensity has beneficial effects on lipid and lipoprotein concentrations of male runners, but does not essentially influence lipid and lipoprotein profiles in female runners.

\section{Introduction}

Coronary heart disease is a serious health problem in most western countries (1). Although the precise etiology of coronary heart disease still needs to be elucidated, a contributing role for elevated serum lipids and lipoproteins has been established. In both men and women total cholesterol, low density lipoprotein cholesterol (LDL-cholesterol) and triacylglycerols are positively correlated to the risk of coronary heart disease, while high density lipoprotein cholesterol (HDL-cholesterol) is inversely related (2-4). In order to manipulate lipoprotein levels, life-style intervention may be attempted prior to pharmacotherapy $(5-6)$. It has been suggested that exercise may protect against ischaemic heart disease, partly through effects on plasma lipids and lipoproteins (7-10). Cross-sectional studies, comparing. endurance trained athletes to sedentary individuals, generally have shown lower concentrations of triacylglycerols, total cholesterol and LDL cholesterol and higher concentrations of HDL cholesterol in sera of the trained subjects $(11-13)$. However the athletes concerned were often involved in vigorous training programmes, so the results of these studies may be biased due to self-selection of physically active subjects $(11,13)$. Less intensive physical conditioning may be more appropriate to elicit long-term improvement in plasma lipoprotein profiles 
for a large population. Longitũdinal studies of individuals exercising on a recreational basis have yielded less marked results, which are often difficult to interpret due to confounding factors like length of the training period, intensity and form of the training programme and diet or weight loss of the individuals under investigation (14-20). Furthermore, most of these studies are restricted to either exercising males or - to a far lesser extent - exercising females (17-20). The present study is designed to investigate the effects of a prolonged training programme of moderate intensity on the lipid status in a group of previously sedentary males and females, while keeping other habitual factors constant.

\section{Materials and Methods}

\section{Subjects}

Threehundred seventy people replied to advertisements in two local newspapers and on a local radio station. Those who participated in any sports such as running or jogging or who were active for more than one hour per week in other recreational sports were excluded. From the remaining group, twenty males aged from 32 to 49 years (median: 39 years) and 14 females aged from 27-41 years (median: 35 years) were aselectly chosen to participate in the study. No lipid lowering or antihypertensive medication was used by any of the volunteers. Among the participants were three female and six male cigarette smokers (maximum of ten cigarettes a day), who continued to smoke during the test period. All individuals kept their diet and other living habits, like the use of alcohol, as constant as possible during the study. After two information sessions all subjects gave their written informed consent.

\section{Training programme}

After a medical examination and pre-exercise control measurements all volunteers participated in a 9 month endurance training programme preparing for a half marathon run $(21 \mathrm{~km})$. The schedule was essentially the same as previously described by Janssen et al. (21). The training period lasted 9 months. After 24 and 36 weeks of training all subjects ran a $15 \mathrm{~km}$ and $21 \mathrm{~km}$ race, respectively. During the general preparation period the volunteers trained 3-4 times a week; 6 weeks before each contest the training programme was intensified to 5-6 times a week. Beside the attention paid to style and technique of running, stretching, speed, intervals, warming-up and cooling-down, the training included three elements: long-distance running, running at high speed and interval training.

\section{Sampling}

All blood samples were drawn between 8.00 and 9.00 am. All subjects were seated and had not eaten or exercised during the preceding ten hours before phlebotomy. Samples were taken before the start of the training programme and, in order to avoid acute effects, five days before both races. Non-traumatic venipuncture was performed by trained technicians. Within one hour from sample collection serum was separated from blood, snap-frozen in aliquots, stored at $-70^{\circ} \mathrm{C}$ in plastic tubes and thawed at $37^{\circ} \mathrm{C}$ immediately prior to serial analysis.

\section{Methods}

Percentage body fat was assessed by measuring skinfold thickness on four sites: biceps, triceps, subscapular and supra-iliac (22). Triacylglycerols and cholesterol were assayed employing fully enzymatic methods and using a Cobas Bio centrifugal fast analyzer (Roche Diagnostica, Basel, Switzerland). All samples were assayed with commercial test kits according to the instructions of the manufacturer. Serum triacylglycerols were determined using a test kit of Roche Diagnostica. Total serum cholesterol was analyzed using a kit of Boehringer Mannheim (Mannheim, Germany). HDL-cholesterol fraction was isolated by the precipitation of chylomicrons, very low density lipoprotein (VLDL)- and LDL-cholesterols from serum by the phosphotungstic acid/magnesium chloride precipitant and determined with a test kit of Boehringer (23). LDL-cholesterol was calculated according to the Friedewald equation (23). The intra-assay coefficient of variation of the tests was less than $5 \%$.

\section{Statistics}

All statistical computations were done with SPSS/PC +4.0 computer package (SPSS Inc., Chicago, USA). Wilcoxon signed rank test was used to compare differences in pre- and post-exercise serum samples. The Mann-Whitney Wilcoxon test was used to compare the male and female population. All data are given as medians and interquartile ranges. Correlations between changes in lipids and lipoproteins and changes in anthropometric values were calculated according to the method of Spearman. Stepwise multiple regression was carried out to find independent determinants for the change in total cholesterol and triacylglycerols.

\section{Results}

\section{Effect of training on anthropometric values}

Table 1 shows median (interquartile range) body weight, body mass index and percentage body fat before and after the training programme in the male and female

Tab. 1 Median (interquartile range) body weight, body mass index and percentage body fat of the male $(\mathrm{N}=20)$ and female $(\mathrm{N}=14)$ group before and after the training programme.

\begin{tabular}{|c|c|c|c|c|}
\hline & Gender & $\begin{array}{l}\text { Before } \\
\text { training programme }\end{array}$ & $\begin{array}{l}\text { After } \\
\text { training programme }\end{array}$ & $\begin{array}{l}\text { p-value } \\
\text { before vs. after }\end{array}$ \\
\hline Body weight (kg) & $\begin{array}{l}0 \\
+\end{array}$ & $\begin{array}{l}74.6(69.1-79.8) \\
63.0(57.0-65.8)^{\mathrm{a}}\end{array}$ & $\begin{array}{l}72.2(64.9-77.7) \\
60.7(55.0-63.4)^{\mathrm{a}}\end{array}$ & $\begin{array}{l}p<0.001 \\
p=0.10\end{array}$ \\
\hline Body mass index $\left(\mathrm{kg} \cdot \mathrm{m}^{-2}\right)$ & $\begin{array}{l}\hat{\delta} \\
\dot{q}\end{array}$ & $\begin{array}{l}23.1(21.6-25.5) \\
21.6(21.3-22.6)^{b}\end{array}$ & $\begin{array}{l}22.0(21.1-24.4) \\
21.5(21.3-22.3)\end{array}$ & $\begin{array}{l}p=0.001 \\
p=0.14\end{array}$ \\
\hline Body fat (\%) & $\begin{array}{l}0 \\
\text { ô }\end{array}$ & $\begin{array}{l}19.2(16.2-24.0) \\
27.1(24.3-30.5)^{\mathrm{a}}\end{array}$ & $\begin{array}{l}14.1(11.1-15.5) \\
24.3(20.7-26.7)^{\mathrm{a}}\end{array}$ & $\begin{array}{l}p=0.002 \\
p=0.003\end{array}$ \\
\hline
\end{tabular}

a Males vs. females: $\mathrm{p}<0.01$

${ }^{b} \mathrm{p}<0.05$ 
Tab. 2 Median (interquartile range) lipid and lipoprotein concentrations in sera of males and females prior to the training programme and 5 days before the $15 \mathrm{~km}$ and $21 \mathrm{~km}$ race, respectively.

\begin{tabular}{|c|c|c|c|c|c|c|c|}
\hline & \multirow{2}{*}{$\begin{array}{l}\text { Gen- } \\
\text { der }\end{array}$} & \multirow[t]{2}{*}{$\mathbf{N}$} & \multirow[t]{2}{*}{ Before } & \multirow[t]{2}{*}{$15 \mathrm{~km}$} & \multirow[t]{2}{*}{$21 \mathrm{~km}$} & \multicolumn{2}{|l|}{ p-value } \\
\hline & & & & & & $\begin{array}{l}\text { Before } \\
\text { vs. } 15 \mathrm{~km}\end{array}$ & $\begin{array}{l}\text { Before } \\
\text { vs. } 21 \mathrm{~km}\end{array}$ \\
\hline $\begin{array}{l}\text { Triacylglycerols } \\
\text { (mmol/l) }\end{array}$ & $\begin{array}{l}\text { d } \\
q\end{array}$ & $\begin{array}{l}20 \\
14\end{array}$ & $\begin{array}{l}1.11(0.91-1.51) \\
0.89(0.65-1.14)^{b}\end{array}$ & $\begin{array}{l}0.93(0.82-1.35) \\
0.87(0.79-1.34)\end{array}$ & $\begin{array}{l}0.92(0.77-1.36) \\
0.73(0.57-1.11)\end{array}$ & $\begin{array}{l}p=0.08 \\
p=0.14\end{array}$ & $\begin{array}{l}p=0.001 \\
p=0.28\end{array}$ \\
\hline $\begin{array}{l}\text { Total cholesterol } \\
(\mathrm{mmol} / \mathrm{l})\end{array}$ & $\begin{array}{l}\delta \\
9\end{array}$ & $\begin{array}{l}19 \\
14\end{array}$ & $\begin{array}{l}5.80(5.00-6.40) \\
5.30(3.90-6.00)\end{array}$ & $\begin{array}{l}5.20(4.70-5.60) \\
5.00(4.60-5.80)\end{array}$ & $\begin{array}{l}5.10(4.45-5.70) \\
4.90(4.70-5.50)\end{array}$ & $\begin{array}{l}\mathrm{p}<0.001 \\
\mathrm{p}=0.38\end{array}$ & $\begin{array}{l}p<0.001 \\
p=0.16\end{array}$ \\
\hline $\begin{array}{l}\text { HDL cholesterol } \\
(\mathrm{mmol} / \mathrm{l})\end{array}$ & $\begin{array}{l}\delta \\
+\end{array}$ & $\begin{array}{l}20 \\
14\end{array}$ & $\begin{array}{l}1.00(0.90-1.25) \\
1.45(1.05-1.85)^{b}\end{array}$ & $\begin{array}{l}1.00(0.90-1.10) \\
1.40(1.20-1.80)^{\mathrm{a}}\end{array}$ & $\begin{array}{l}1.00(0.95-1.10) \\
1.40(1.10-1.60)^{b}\end{array}$ & $\begin{array}{l}p=0.51 \\
p=0.97\end{array}$ & $\begin{array}{l}p=0.75 \\
p=0.18\end{array}$ \\
\hline $\begin{array}{l}\text { LDL cholesterol } \\
(\mathrm{mmol} / \mathrm{l})\end{array}$ & $\begin{array}{l}\delta \\
+\end{array}$ & $\begin{array}{l}19 \\
14\end{array}$ & $\begin{array}{l}3.98(3.32-4.81) \\
3.18(2.49-3.92)^{b}\end{array}$ & $\begin{array}{l}3.59(3.14-4.15) \\
3.05(2.57-3.39)^{b}\end{array}$ & $\begin{array}{l}3.48(3.13-4.13) \\
3.28(2.67-3.80)\end{array}$ & $\begin{array}{l}p=0.01 \\
p=0.15\end{array}$ & $\begin{array}{l}p=0.001 \\
p=0.22\end{array}$ \\
\hline
\end{tabular}

a Males vs. females: $p<0.01$

${ }^{b} \mathrm{p}<0.05$

group. Both men and women experienced a weight reduction. In the male group, the median post-training body weight and body mass index were significant lower than the median pre-training values $(p<0.01)$. A significant decrease of percentage body fat $(p<0.01)$ was noticed in both male and female groups.

\section{Effect of training on serum lipids and lipoproteins}

Median (interquartile range) serum triacylglycerols, total cholesterol, LDL cholesterol and HDL cholesterol of the male and female group prior to the training programme, 5 days before the $15 \mathrm{~km}$ and $21 \mathrm{~km}$ race, respectively, and the changes after nine months of training, are shown in table 2 and figure 1. A significant decrease of the median triacylglycerol concentration at the end of the training programme in comparison to pre-training levels $(p<0.01)$ was only observed in the male group. Furthermore, the median triacylglycerol concentration decreased significantly during the training period $(p<0.01)$, as did LDL cholesterol $(p<0.01)$ again only in the male group. Neither in the male nor female population did HDL cholesterol change significantly during the test period. The median serum HDL cholesterol concentration in the female group remained significantly higher in comparison to the median serum HDL cholesterol in the male group $(p<0.05)$.

\section{Correlation analysis of serum lipids and lipoproteins}

Table 3 shows the coefficients of correlation (Spearman) between the changes in body weight, body mass index and percentage body fat and the changes in serum lipid and lipoproteins for the total group. These findings did not show a significant correlation between reductions in body weight and changes in serum lipids or lipoproteins.

\section{Multiple regression}

In the multiple regression model, dependent variables were the change in total cholesterol ( $\Delta$ total cholesterol) and the change in triacylglycerols ( $\Delta$ triacylglycerols). Independent variables for $\Delta$ total cholesterol were: age,



Fig. 1 Median (interquartile range) serum triacylglycerols, total cholesterol and HDL cholesterol in 20 men (O) and 14 women ( $\square$ ) before the training programme, and 5 days before the $15 \mathrm{~km}$ and $21 \mathrm{~km}$ race, respectively. 
Tab. 3 Correlation (Spearman) between changes $(\Delta)$ in serum lipids, lipoproteins and changes in anthroprometric values after nine months of training $(\mathrm{N}=34)$.

\begin{tabular}{lllll}
\hline & $\begin{array}{l}\Delta \mathrm{LDL} \\
\text { cho- } \\
\text { lesterol }\end{array}$ & $\begin{array}{l}\Delta \text { Triacyl- } \\
\text { glycerols }\end{array}$ & $\begin{array}{l}\Delta \mathrm{HDL} \\
\text { cho- } \\
\text { lesterol }\end{array}$ & $\begin{array}{l}\Delta \text { Total } \\
\text { cho- } \\
\text { lesterol }\end{array}$ \\
\hline $\begin{array}{l}\Delta \text { Weight } \\
\begin{array}{c}\Delta \text { Body } \\
\text { mass index }\end{array}\end{array}$ & 0.08 & 0.04 & 0.12 & 0.41 \\
$\Delta$ Body fat $^{\mathrm{a}}$ & 0.08 & 0.04 & 0.15 & 0.40 \\
\hline
\end{tabular}

a 13 missing values

sex, change in body weight ( $\Delta$ weight), change in body mass index ( $\Delta$ body mass index), $\Delta$ triacylglycerols and total cholesterol concentration before the training programme (total cholesterol 1) $\left(\mathrm{R}^{2}=0.621, \mathrm{~F}=6.83\right.$, $\mathrm{p}<0.001 ; \mathrm{n}=32$ ). Independent variables for $\Delta$ triacylglycerols were: age, sex, change in body weight $(\Delta$ weight), change in body mass index ( $\Delta$ body mass index) and triacylglycerol concentration before the training programme (triacylglycerols 1$) \quad\left(R^{2}=0.437\right.$, $\mathrm{F}=4.03, \mathrm{p}<0.01 ; \mathrm{N}=32$ ). In the stepwise multiple regression for $\Delta$ total cholesterol and $\Delta$ triacylglycerols in the total group, the highest correlation was found with the initial total cholesterol and triacylglycerols concentrations: $\mathrm{R}^{2}=0.57$ and 0.36 , respectively; figure 2 shows the correlation between $\Delta$ total cholesterol and total cholesterol concentrations. For $\Delta$ total cholesterol no other variables were selected. Excluding the triacylglycerols 1 level in the stepwise model, an independent predictor of the variance in the $\Delta$ triacylglycerols was $\Delta$ weight $\left(\mathrm{R}^{2}=0.21\right)$.

\section{Discussion}

Elevated concentrations of triacylglycerols, total cholesterol and its principal carrier LDL cholesterol, constitute a major risk factor for cardiovascular disease, while HDL cholesterol has an inverse relationship with coronary heart disease (2-4). Many exogenous factors influence lipid and lipoprotein concentrations, like diet, body composition, alcohol consumption and medication $(5-7,25)$. Prolonged exercise may have favourable effects on plasma lipids and lipoproteins and therefore constitute a non-pharmacological approach to lipoprotein therapy $(5,7,9,10)$. Cross-sectional studies have shown that endurance athletes generally have lower concentrations of triacylglycerols, total cholesterol and LDL cholesterol and higher levels of HDL cholesterol (1113, 26). However, cross-sectional studies have methodological limitations because of genetic differences and differences in life-style of the participants and definite conclusions cannot be drawn $(11,13)$. In longitudinal studies, the benefits of exercise on blood lipid and lipoprotein levels are modest and often contradictory (1418). The changes in serum lipoprotein levels seem to be dependent on the duration and intensity of the training programme and whether or not weight is lost concomitantly $(14,17,26,27)$. In our study, although all individuals maintained their usual diet, both men and women lost body weight and body fat, mainly caused by an increased energy expenditure due to the more active lifestyle. Because the decrease in body weight and body mass index was not significant in the female group, a reduction in skinfold thickness pointed toward a redistribution of body fat or replacement of fat tissue to muscle tissue due to the training regimen (18). In general, the present long-term exercise programme affected blood lipids in men more than in women. In the female group, the 9 month aerobic endurance exercise programme induced only small and statistically non-significant changes in serum lipid or lipoprotein levels. These findings are consistent with results of other longitudinal studies that failed to demonstrate improved lipid profiles among female exercisers $(18,28-31)$. However, the investigation of the independent effect of exercise in women is complicated because of the influence of reproductive hormones on serum lipids $(18,29,31)$. Furthermore, the number of women under investigation in this study could have been too small to find marginal changes statistically significant. In the male group, the significant decrease of total cholesterol, also observed in other longitudinal studies $(14,26,32-34)$, was mainly attributed to the decrease in LDL cholesterol since HDL-cholesterol remained essentially unchanged. Some studies showed that the reduction in serum total cholesterol and LDL cholesterol is mainly caused by the exer-



Fig. 2 Correlation between the initial cholesterol level (total cholesterol) and the changes in total cholesterol ( $\Delta$ total cholesterol) after nine months of training in sera of 20 men $(0)$ and 14 women ( $\square$ ) 
cise induced weight loss (35). However, in this study no significant relation was found between the change in serum lipoprotein concentrations and the change in either body weight, body mass index or body fat, suggesting that exercise by itself influenced serum cholesterol concentrations. In one study in which four different diets were compared during an exercise programme, it was concluded that physical activity rather than diet is responsible for alterations in VLDL-LDL cholesterol but that the amount of cholesterol intake is an important factor for an increase in HDL cholesterol (27). During the training programme the subjects in our study maintained their dietary intake as unaltered as possible, which could explain the fact that no change in HDL cholesterol was observed for the individuals in the present study. In other studies a modest exercise induced increase in HDL cholesterol was observed, which was mainly caused by an increase in HDL cholesterol-2 (20, $32,34,36)$. The elevated HDL-cholesterol levels in the sera of the female participants in comparison to HDL cholesterol levels of the male runners is a well known finding which is, apart from differences in steroid hor-

\section{References}

1. Nieman DC. Fitness and Sports Medicine. An introduction. Palo Alto Ca, USA: Bull Publishing Company, 1990.

2. Rhoads GG, Gulbrandsen CL, Kagan A. Serum lipoproteins and coronary heart disease in a population study of Hawaii Japanese men. N Engl J Med 1976; 294:293-8.

3. Gordon T, Castelli WP, Hjortland MC, Kannel WB, Dawber TR. High density lipoprotein as a protection factor against coronary heart disease: the Framingham Study. Am J Med 1977; 62:707-14.

4. Criqui MH, Heiss MPHG, Cohn R, Cowan LD, Suchindran $\mathrm{CM}$, Bangdiwala $\mathrm{S}$ et al. Plasma triglyceride level and mortality from coronary heart disease. N Engl J Med 1993; 328:1220-5.

5. Wood PD, Stefanick ML, Dreon DM, Frey-Hewitt B, Caray SC. Changes in plasma lipids and lipoproteins in overweight men during weight loss through dieting as compared with exercise. N Engl J Med 1998; 319:1173-9.

6. Høstmark AT, Berg J, Brudal S, Berge SR, Kierulf P, Bjerkdal T. Coronary risk factors in middle-aged men as related to smoking, coffee intake and physical activity. Scand J Soc Med 1992; 4:196-203.

7. Leon AS. Physiological interactions between diet and exercise in the etiology and prevention of ischaemic heart disease. Ann Clin Res 1988; 20:114-20.

8. Paffenbarger RS, Hyde RT, Wing AL, Hsieh C. Physical activity, all-cause mortality, and longevity of college alumni. $\mathrm{N}$ Engl J Med 1986; 314:605-13.

9. Ekelund L-G, Haskell WL, Johnson JL, Whaley FS, Criqui MN, Sheps DS. Physical fitness as a predictor of cardiovascular mortality in asymptomatic North American men. N Engl J Med 1998; 319:1379-84.

10. Sandvik L, Erikssen J, Thaulow E, Erikssen G, Mundal R, Rodahl K. Physical fitness as a predictor of mortality among healthy, middle-aged Norwegian men. N Engl J Med 1993; 328:533-7.

11. Mena P, Maynar M, Campillo JE. Plasma lipid concentrations in professional cyclists after competitive cycle races. Eur $\mathrm{J}$ Appl Physiol 1991; 62:349-52. mones, attributed to differences in body fat distribution and waist-to-hip ratio between both sexes $(25,37)$. In the present study, median serum triacylglycerol concentrations decreased significantly in the male group together with a non-significant decrease in the female group during the course of the nine month test period. The decrease in serum triacylglycerols did not correlate significantly with the decrease in body weight, body mass index or percentage body fat after nine months. Furthermore, multiple regression analysis revealed that the fall in serum triacylglycerols was, like the fall in serum total cholesterol, mostly dependent on initial serum levels prior to the exercise programme. These findings support the view that exercise by itself and not only weight loss through exercise influences lipid and lipoprotein levels.

In conclusion, the results of the present study demonstrate that a nine month training programme of moderate intensity improves lipid and lipoprotein profiles in male runners but has only minimal influence on lipid and lipoprotein levels in female runners.

12. Northcote RJ, Canning GC, Todd IC, Ballantyne D. Lipoprotein profiles of elite veteran endurance athletes. Am J Cardiol 1988; 61:934-6.

13. Stray-Gundersen J, Denke MA, Grundy SM. Influence of lifetime cross-country skiing on plasma lipids and lipoproteins. Med Sci Sports Exerc 1991; 23:695-702.

14. Després JP, Tremblay A, Moorjani S, Lupien PJ, Thériault G, Nadeau A, Bouchard C. Long-term exercise training with constant energy intake. 3: Effects on plasma lipoprotein levels. Int J Obesity 1990; 14:85-94.

15. Thompson PD, Cullinane EM, Sady SP, Flynn MM, Bernier DN, Kantor MA, Saritelli AC, Herbert PN. Modest changes in high-density lipoprotein concentration and metabolism with prolonged exercise training. Circulation 1988; 78:25-34.

16. Superko HR. Exercise training, serum lipids, and lipoprotein particles: is there a change threshold? Med Sci Sports Exerc 1991; 23:677-85.

17. Raz I, Rosenblit H, Kark JD. Effect of moderate exercise on serum lipids in young men with low high density lipoprotein cholesterol. Arteriosclerosis 1988; 8:245-51.

18. Blumenthal JA, Matthews K, Frederikson M, Rifai N, Schniebolk S, German D et al. Effects of exercise training on cardiovascular function and plasma lipid, lipoproteins, and apolipoprotein concentrations in premenopausal and postmenopausal women. Arteriosclerosis Thromb 1991; 11:912-7.

19. Findlay $\mathbb{N}$, Taylor RS, Dargie HJ, Grant S, Pettigrew $A_{2}$ Wilson, JT et al. Cardiovascular effects of training for a marathon run in unfit middle aged men. $\mathrm{Br}$ Med J 1987; 295:521-4.

20. Aellen R, Hollmann W, Boutellier U. Effects of aerobic and anaerobic training on plasma lipoproteins. Int $\mathrm{J}$ Sport Med 1993; 14:396-400.

21. Janssen GME. Marathon running: functional changes in male and femalc subjects during training and contests. Int $J$ Sports Med 1989; 10 (Suppl), 117S-90S.

22. Durnin JVGA, Womersley J. Body fat assessed from total body density and its estimation from skinfold thickness: measurements on 481 men and women aged from 16 to 72 years. Br J Nutr 1974; 32:77-97. 
23. Seigler $\mathrm{L}$, Wu WT. Separation of serum high-density lipoprotein for cholesterol determination: ultracentrifugation vs precipitation with sodium phosphotungstate and magnesium chloride. Clin Chem 1981; 27:838-41.

24. Friedewald WT, Levy RI, Frederickson DS. Estimation of the concentration of low-density-lipoprotein cholesterol in plasma without use of the preparative ultracentrifuge. Clin Chem 1972; 18:499-509.

25. Marti B, Suter E, Riesen WF, Tschopp A, Wanner H-U. Anthropometric and lifestyle correlates of serum lipoprotein and apolipoprotein levels among normal non-smoking men and women. Atherosclerosis 1989; 75:111-22.

26. Williams PT. Weight set-point theory predicts HDL-cholesterol levels in previously obese long-distance runners. Int $\mathrm{J}$ Obe 1990; 14:421-7.

27. Ekstedt B, Jönsson E, Johnson O. Influence of dietary fat, cholesterol and energy on serum lipids at vigorous physical exercise. Scand J Clin Lab Invest 1991: 51:437-42.

28. Perry AC, Shaw MH, Hsia L, Nash MS, Kaplan T, Signorile JF. Plasma lipid levels in active and sedentary premenopausal females. Int J Sports Med 1992; 13:210-5.

29. Taylor PA, Ward A. Women, high density lipoprotein cholesterol, and exercise. Arch Intern Med 1993; 153:1178-84.

30. McNaughton L, Davies P. The effects of a 16 weeks aerobic conditioning program on serum lipids, lipoproteins and coronary risk factors. J Sports Med 1987; 27:296-302.

31. Moll ME, Williams RS, Lester RM, Quartfordt SH, Wallace AG. Cholesterol metabolism in non-obese women. Atherosclerosis $1979 ; 34: 159-66$.
32. Hespel P, Lijnen $P$, Fagard S, Van Hoof R, Rossenen M, Amery A. Changes in plasma lipids and apoprotein associated with physical training in middle-aged sedentary men. Am Heart $J$ 1988; 115:786-92.

33. Mendoza SG, Carrasco H, Zerpa A, Briceno Y, Rodriquez F, Speirs J, Glueck CJ. Effect of physical training on lipids, lipoproteins, apolipoproteins, lipases, and endogenous sex hormones in men with premature myocardial infarction. Metabolism 1991; 40:368-77.

34. Rönnemaa T, Mamiemi J, Puukka P, Kuusi T. Effects of longterm physical exercise on serum lipids. Lipoprotein and lipid metabolizing enzymes in type 2 (non-insulin dependent) diabetic patients. Diabetes Res 1988; 7:79-84.

35. Tran SV, Weltman A. Differential effects of exercise on serum lipid and lipoprotein levels seen with changes in body weight. A meta-analysis. J Am Med Ass 1985; 254:919-24.

36. Williams PT, Krauss RM, Vranizan KM, Wood PDS. Changes in lipoprotein subfractions during diet-induced and exerciseinduced weight loss in moderately overweight men. Circulation 1990; 81:1293-1304.

37. Freedman DS, Jacobsen SJ, Barboriak JJ, Sobocinsky KA, Anderson AJ. Body fat distribution and male/female differences in lipids and lipoproteins. Circulation 1990; 81:1498-1506.
G. A. E. Ponjee
Diagnostic Centre SSDZ
P. O. Box 5010
NL-2600 GA Delft
The Netherlands 